\title{
Breast Fibrocystic Change, Non- Proliferative Type
}

National Cancer Institute

\section{Source}

National Cancer Institute. Breast Fibrocystic Change, Non-Proliferative Type. NCI

Thesaurus. Code C6943.

Breast fibrocystic change characterized by the absence of epithelial cell hyperplasia. 